\title{
Revised Pre-Devensian glacial stratigraphy in Norfolk, England, based on mapping and till provenance
}

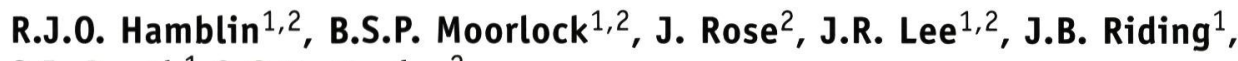 \\ S.J. Booth ${ }^{1}$ \& S.M. Pawley ${ }^{2}$
}

1 British Geological Survey, Keyworth, Nottingham, NG12 5GG, U.K.

2 Department of Geography, Royal Holloway, University of London, Egham, Surrey, TW20 OEX, U.K.

Corresponding author Dr. R.J.0. Hamblin; email: rjoh@bgs.ac.uk

Manuscript received: October 2003; accepted: November 2004

\begin{abstract}
Mapping combined with till provenance studies have resulted in a re-appraisal of the pre-Devensian glacial stratigraphy of Norfolk, England. The traditional model invoked two formations, a North Sea Drift Formation (NSDF) overlain by a Lowestoft Formation, formed by co-existing icesheets originating in Scandinavia and Northern Britain respectively. The NSDF included three diamictons, the First, Second and Third Cromer tills. The Briton's Lane Sands and Gravels were considered to overlie the Lowestoft Formation. However, our work has shown this stratigraphy to be untenable, and we propose a model of several glaciations instead of co-existing ice-sheets. In our revised stratigraphy, the oldest formation, the Happisburgh Formation (including the Happisburgh or First Cromer Till) includes massive, sandy tills derived from northern Britain. The overlying Lowestoft Formation, including the Second Cromer (Walcott) Till is confirmed as derived from the west, introducing much Jurassic material as well as Chalk. The Sheringham Cliffs Formation includes both brown sandy tills (the Third Cromer Till) and 'marly drift', in a variety of tectonic relationships, and derived from the north and NNW. Finally the Briton's Lane Formation is the only formation to include Scandinavian erratics. Dating of the four formations is at varying levels of confidence, with the Lowestoft Formation most confidently confirmed as MIS 12 . The Happisburgh Formation is believed to represent an earlier glaciation, and MIS 16 is proposed. The Sheringham Cliffs Formation is tentatively believed to date from MIS 10, and the Briton's Lane Formation is assigned to MIS 6.
\end{abstract}

Keywords: England, Norfolk, Pleistocene, glacigenics

\section{Introduction}

Norfolk possesses some of the most extensive, thickest, and, by virtue of its long coastline, best exposed glacial sequences in the British Isles. These have traditionally been divided into three glacigenic formations, and in recent times these have been formally termed the North Sea Drift Formation, Lowestoft Formation, and Hunstanton Formation (Bowen et al., 1999). The North Sea Drift and Lowestoft formations were ascribed to the Anglian Glaciation (Marine Oxygen Isotope Stage 12), while the Hunstanton Formation is ascribed to the Devensian Glaciation, MIS 2 (Bowen et al., 1999).
The Anglian formations were believed to derive from two distinct ice sheets, the 'Scandinavian Ice Sheet', which entered the area from the north or north-north-east, and the 'British Eastern Ice Sheet', which entered from the west (Perrin et al., 1979; Ehlers \& Gibbard, 1991; Lunka, 1994). In general it was believed that the deposits of the North Sea Drift Formation were derived from the former ice sheet, since they were believed to be characterised by a suite of igneous and metamorphic erratics from the 0slofjord region and southwestern Norway, while the deposits of the Lowestoft Formation were derived from the latter ice sheet, and contain erratics derived from the Mesozoic outcrops to the north-west, principally the 
Table 1. Previous pre-Devensian till stratigraphies as applied to North-East Norfolk

\begin{tabular}{|c|c|c|c|c|}
\hline Banham $(1968,1988)$ & Hart \& Boulton (1991) & Lunkka (1994) & Bowen et al. (1999) & \\
\hline \multicolumn{4}{|l|}{ Briton's Lane Sand \& Gravel } & \multirow{6}{*}{ Anglian (MIS 12) } \\
\hline \multicolumn{2}{|l|}{ Lowestoft Till = Marly Drift } & $\begin{array}{l}\text { Lowestoft Till Formation, } \\
\text { Marly Drift Member }\end{array}$ & Lowestoft Formation & \\
\hline \multirow[t]{2}{*}{ Third Cromer Till } & Walcott Diamicton Member & Cromer Diamicton Member, & \multirow{4}{*}{$\begin{array}{l}\text { North Sea } \\
\text { Dift Formation }\end{array}$} & \\
\hline & & Mundesley Diamicton Member & & \\
\hline Second Cromer Till & Eccles Diamicton Member & Walcott Diamicton Member & & \\
\hline First Cromer Till & Happisburgh Diamicton Member & Happisburgh Diamicton Member & & \\
\hline
\end{tabular}

Chalk (Upper Cretaceous) and the Kimmeridge Clay (Upper Jurassic). However, it has generally been believed that the two ice sheets co-existed (Hart \& Boulton, 1991).

In north-east Norfolk, three tills were recognised within the North Sea Drift Formation. These were initially named the First, Second and Third Cromer tills (Table 1; Banham, 1968, 1988), of which the middle one was noticeably more calcareous than the others. Alternative formal names were later assigned to these three tills by Hart and Boulton (1991) and Lunkka (1994) (Table 1). The Lowestoft Formation was believed to overlie the North Sea Drift Formation, although in north Norfolk it was represented by the 'marly drift', formed almost wholly of reconstituted Chalk, with little or no Jurassic content. A further unit of relevance here is the Briton's Lane Sand and Gravel, recorded by Banham $(1968,1988)$ as overlying the Lowestoft Formation; Boulton et al. (1984) proposed a Wolstonian age (MIS 8-6?) for the Third Cromer Till and the Briton's Lane Sands and Gravels.

In recent years, mapping by the British Geological Survey (1: 50000 sheets 130 Wells-next-the-sea, 131 Cromer, 132 Mundesley, 148 North Walsham, and 176 Lowestoft), and analytical work at Royal Holloway University of London, have led to a complete re-appraisal of this stratigraphy. Summary analytical details are given in Tables 2 to 4, the comprehensive data can be found in Lee et al. (2004b). Mapping in north-east Norfolk indicates that the Walcott Till (Second Cromer Till) is a member of the Lowestoft Formation. This correlation of course demolishes the concept of the North Sea Drift Formation, since the Lowestoft Formation cannot co-exist in the middle of the North Sea Drift Formation. Further, mapping indicates that the 'marly drift' is associated with the Third Cromer Till and not with the Lowestoft Formation; the Third Cromer Till and the overlying 'marly drift' lie stratigraphically between the Lowestoft Formation and the Briton's Lane Sand and Gravel. Finally, clast provenance has demonstrated that the First and Third Cromer tills of the old North Sea Drift Formation show no evidence of Scandinavian derivation (Lee et al., 2002; Lee, 2003). Scandinavian erratics have only been found in the Briton's Lane Sand and Gravel, and it is believed that erratics washed down the cliffs from this deposit and possibly incorporated into the lower tills by land-slipping or wave action have led to erroneous conclusions being drawn in the

Table 2. The revised pre-Devensian stratigraphy proposed in this paper, with abbreviated details of provenance interpretation and allochtonous palynology.

\begin{tabular}{|c|c|c|c|c|}
\hline Formation & Members named in this paper & $\begin{array}{l}\text { Proposed } \\
\text { MIS age }\end{array}$ & $\begin{array}{l}\text { Provenance } \\
\text { interpretation }\end{array}$ & Allochtonous palynology \\
\hline Briton's Lane Formation ${ }^{1}$ & Briton's Lane Sand and Gravel Member & 6 & $\begin{array}{l}\text { North Sea, Scandinavia, } \\
\text { North Britain }\end{array}$ & \\
\hline \multirow[t]{4}{*}{ Sheringham Cliffs Formation ${ }^{2}$} & Weybourne Town Till Member & & North Sea & $\begin{array}{l}\text { Upper Cretaceous dominant, } \\
\text { Carboniferous and Jurassic rare }\end{array}$ \\
\hline & Runton Till Member & & North Sea, North Britain & Jurassic dominant, much \\
\hline & Bacton Green Till & 10 & & Carboniferous \& Cretaceous, \\
\hline & Member (Third Cromer Till) & & & little Palaeogene \& Quaternary \\
\hline \multirow[t]{3}{*}{ Lowestoft Formation } & Walcott Till Member & & North-east \& eastern & Jurassic dominant; \\
\hline & (Second Cromer Till) & 12 & Britain & little Carboniferous, Cretaceous \\
\hline & Lowestoft Till Member & & & or Cenozoic \\
\hline \multirow[t]{3}{*}{ Happisburgh Formation } & Corton Till Member & & North Sea, North Britain & Westphalian dominant, \\
\hline & Happisburgh Till Member & 16 & & Jurassic common; also Cretaceous, \\
\hline & (First Cromer Till) & & & Cenozoic \\
\hline
\end{tabular}

1 Briton's Lane Formation replaces the provisional Overstrand Formation (Hamblin et al., 2000, 2003)

2 Sheringham Clifs Formation replaces the provisional Beeston Regis Formation (Hamblin et al., 2000, 2003) 


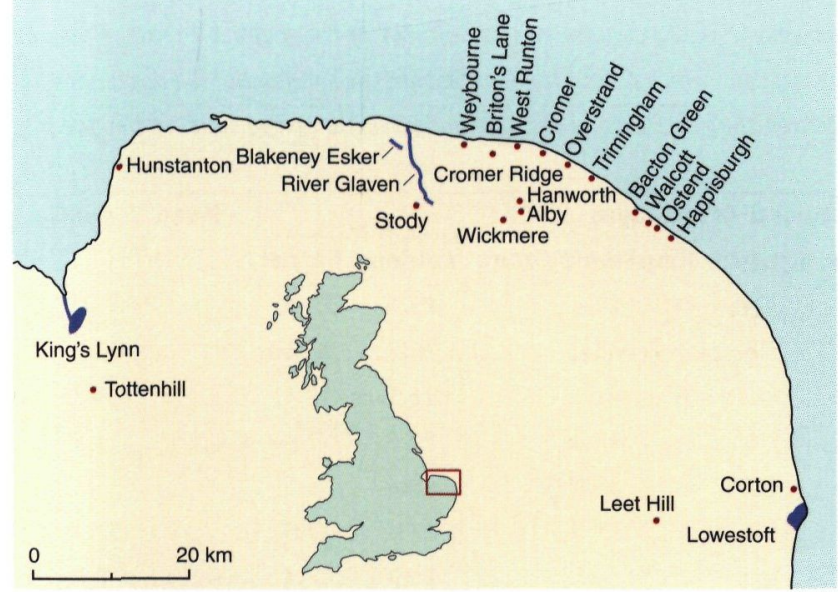

Fig. 1. Location diagram, showing all places in East Anglia named in the text.

past, or else Scottish porphyries, not true rhomb porphyries, have been mis-identified. A letter to Quaternary Newsletter (Moorlock et al., 2001) asking for examples of Scandinavian erratics collected from the lower tills produced no positive replies. As a result of our discoveries a new stratigraphy has steadily evolved (Hamblin, 2000; Hamblin et al., 2000; Moorlock et al., 2000a; Lee et al., 2004b), and the current state of play is shown as Table 2.

\section{Description and derivation of the pre-Devensian tills}

The Happisburgh Formation includes two till members, the Happisburgh and Corton tills: Happisburgh Formation has superceded Corton Formation (Arthurton et al., 1994) since the deposits are best exposed at Happisburgh (Fig. 1), where both tills are present. The basal Happisburgh Till outcrops between Happisburgh and 0stend, and between Trimingham and Overstrand, and has been recorded as far west as Wickmere, while the overlying Corton Till outcrops discontinuously from Corton to Happisburgh. Both are highly consolidated, matrixsupported diamictons with a matrix of clayey sand, and exhibit similar clast, heavy mineral, $\mathrm{CaCO}_{3}$ and palynomorph content. The massive Happisburgh Till is interpreted as a subglacial deformation till deposited by ice flowing from between northwest and northeast, while the Corton Till is mainly subaqueous (Lee, 2001). The tills are clast-poor, with most clasts smaller than $32 \mathrm{~mm}$. The clasts are dominantly rounded and angular flint, vein quartz, quartzite, chalk and shell, with less common Devonian and Triassic sandstone, Jurassic limestone, Permian Magnesian Limestone, Carboniferous Limestone, coal, various metasediments, porphyry, basalt, granite and granodiorite (Table 3 ). This erratic suite is consistent with derivation from northern Britain, but no evidence has been found of a Scandinavian source (Lee et al., 2002). High levels of amphiboles and epidote in the heavy mineral content (Table 4) are consistent with derivation from North Sea seabed sediments (Lee et al., 2004b).

Allochthonous palynomorphs in the Happisburgh Formation tills include Westphalian spores (very common), Jurassic (less common), Cretaceous, particularly Lower Cretaceous dinoflagellate cysts, Cenozoic spores and pollen, and Paleogene dinoflagellate cysts (Riding, 1999, 2002a). These associations confirm derivation from northern Britain and the North Sea, with the Cenozoic spores and pollen and Paleogene dinoflagellate cysts deriving from the North Sea, Lower Cretaceous

Table 3. Clast content of the till members within the study area; clast counts were performed on the $4-8 \mathrm{~mm}$ gravel fraction.

\begin{tabular}{|c|c|c|c|c|c|c|c|c|}
\hline \multirow[t]{2}{*}{ Formation } & \multirow[t]{2}{*}{ Member } & \multicolumn{5}{|c|}{ Reworked sedimentary } & \multicolumn{2}{|c|}{$\begin{array}{l}\text { Reworked igneous } \\
\text { and metamorphic }\end{array}$} \\
\hline & & Pleistocene & Cretaceous & Jurassic & Permo-Trias & Carboniferous & $\begin{array}{l}\text { Scotland \& } \\
\text { NE England }\end{array}$ & Scandinavia \\
\hline Briton's Lane & Briton's Lane Sand & 19.9 & 62.6 & 1.3 & 10.3 & 0.7 & 4.7 & 0.1 \\
\hline Formation & and Gravel Member & & & & & & & \\
\hline Sheringham & Weybourne Town Till Member & 15.3 & 83.6 & 0.1 & 0.6 & 0.0 & 0.4 & 0.0 \\
\hline \multirow[t]{2}{*}{ Cliffs Formation } & Runton Till Member & 69.9 & 20.5 & 1.8 & 0.8 & 0.0 & 3.4 & 0.0 \\
\hline & Bacton Green Till Member & 75.0 & 16.7 & 2.0 & 1.8 & 0.0 & 2.5 & 0.0 \\
\hline Lowestoft & Walcott Till Member & 49.6 & 42.9 & 3.2 & 0.6 & 0.3 & 2.4 & 0.0 \\
\hline Formation & Lowestoft Till Member & 8.5 & 82.7 & 8.2 & 0.0 & Trace & 0.2 & 0.0 \\
\hline Happisburgh & Corton Till Member & 91.1 & 3.7 & 3.3 & 0.0 & 0.0 & 0.6 & 0.0 \\
\hline Formation & Happisburgh Till Member & 68.1 & 22.8 & 1.7 & 0.4 & 0.4 & 4.3 & 0.0 \\
\hline
\end{tabular}

Expansion of clast lithology headings: reworked Pleistocene: brown and white flint, vein quartz, chatter-marked flint, quartzose lithologies, Rhaxella chert, Carboniferous chert, Greensand chert, shell, wood; Cretaceous: chalk, black flint, Carstone, glauconitic sandstone; Jurassic: sandstone, limestone (including oolites), ironstone, shell; Permo-Triassic: brick red sandstone, evaporite, Magnesian limestone; Carboniferous: coal, limestone, ironstone; Scotland \& NE England: Dalradian metasediments, olivine and porphyritic basalt, acid porphyry, andesite, granitoids, quartz dolerite, Cheviot granite; Scandinavia: rhomb porphyry, larvikite, nordmarkite, high-grade metamorphics. Sources: Lee (2003), Lee et al. (2002, 2004b), Pawley et al. (2004). 
Table 4. Mean heavy mineral composition (at one standard deviation) and calcium carbonate content of the matrices of the major till units, from Lee et al. (2004b). Heavy mineral analysis was performed on the 63 - $125 \mu \mathrm{m}$ fine sand fraction which proved the most diagnostic sub-fraction on discriminating between units. Separation and counting were undertaken using standard procedures (Gale \& Hoare, 1991), with 500 - 700 grains counted per sample.

\begin{tabular}{|c|c|c|c|c|c|c|c|}
\hline \multirow[t]{2}{*}{$\overline{\text { Formation }}$} & \multirow[t]{2}{*}{ Member } & \multicolumn{5}{|c|}{ Heavy Mineral Percentages } & \multirow[t]{2}{*}{ Mean $\% \mathrm{CaCO}_{3}$} \\
\hline & & Opaques & Apatite & Amphibole Group & Epidote & Garnet & \\
\hline Briton's Lane Formation & Briton's Lane Sand and Gravel Member & 55.1 & 1.4 & 21.9 & 26.6 & 22.3 & \\
\hline Sheringham & Weybourne Town Till Member & 40.2 & 3.8 & 38.0 & 18.7 & 23.3 & 68.7 \\
\hline \multirow[t]{2}{*}{ Cliffs Formation } & Runton Till Member & 41.7 & 2.0 & 41.1 & 22.1 & 18.4 & 14.7 \\
\hline & Bacton Green Till Member & 30.0 & 1.6 & 42.3 & 22.8 & 17.4 & 11.3 \\
\hline \multirow[t]{2}{*}{ Lowestoft Formation } & Walcott Till Member & 36.7 & 6.2 & 38.8 & 19.4 & 15.8 & 36.2 \\
\hline & Lowestoft Till Member & 55.8 & 16.4 & 27.7 & 17.0 & 17.8 & 32.1 \\
\hline \multirow[t]{2}{*}{ Happisburgh Formation } & Corton Till Member & 29.0 & 1.6 & 39.5 & 23.4 & 17.4 & 8.4 \\
\hline & Happisburgh Till Member & 28.8 & 2.7 & 40.2 & 23.7 & 15.6 & 12.3 \\
\hline
\end{tabular}

dinoflagellate cysts consistent with derivation from the Speeton Clay of Yorkshire, and the provenance of Westphalian spores being north-eastern England or eastern Scotland, there being no Carboniferous outcrops between Norway and Norfolk.

The Lowestoft Formation tills differ from those of the Happisburgh Formation by their higher content of $\mathrm{CaCO}_{3}$ (Table 4), both in the matrix and as chalk clasts, their lower sand and higher silt and clay content, and their higher content of opaque heavy minerals and apatite (Table 4) (Perrin et al., 1973, 1979; Arthurton et al., 1994; Lee et al., 2004b). The typical lithology of the Lowestoft Till Member is dark grey or olive grey silt- and clay-rich, matrix-supported diamicton. The matrix is dominantly derived from the Kimmeridge Clay and other Mesozoic argillaceous rocks. Clasts are dominated by chalk (typically $>80 \%$ ), and flint, but also include other Mesozoic limestones and sandstones, quartz and quartzite, and a wide range of fossils from the Lower and Middle Jurassic (Lias to Kimmeridge Clay) (Table 3). The Walcott Till Member, interpreted as a sub-glacial deforming-bed till deposited by ice from the north-west (Lee, 2003), contains more amphibole and epidote than the Lowestoft Till Member, and more Pleistocene rounded flints, implying a greater North Sea input.

Allochthonous palynomorphs in the Lowestoft Formation confirm the derivation from eastern Britain. The till from the type site of the formation at Corton was dominated by dinoflagellate cysts from the Lower Kimmeridge Clay, with low proportions of Carboniferous and Callovian/0xfordian palynomorphs and, surprisingly, no Cretaceous or Quaternary marker forms (Riding, 2002a). Similar analysis of a sample of Walcott Till from Trimingham revealed an abundant palynoflora dominated by Jurassic species (72\%), mainly Kimmeridgian and including diverse and abundant dinoflagellate cysts. Carboniferous spores accounted for only $2.8 \%$ of the sample, and again surprisingly, Cretaceous forms accounted for only $3.5 \%$, with Quaternary, 20\% (Riding, 2001).

The Sheringham Cliffs Formation includes both brown, sandy tills and 'marly drift'. The former vary from heterogenous assemblages including both massive, matrix-supported diamicton and beds of stratified sand with dropstones (Bacton Green Till Member) to massive, unstratified sandy diamicton (Runton Till Member). The Bacton Green Till contains rather more clasts than the Happisburgh Formation tills, but of similar lithologies: much flint, quartz and quartzite, sediments of Cretaceous, Jurassic, Permo-Triassic, Carboniferous and Devonian derivation, and igneous erratics of northern British derivation (Table 3 ). Heavy mineral assemblages are also very similar to the Happisburgh tills (Table 4). The Bacton Green and Runton tills are interpreted as subaqueous flow till and subglacial deformation till respectively (Lee, 2003; Lee et al., 2004b).

The allochthonous palynology of the Bacton Green Till is dominated by Lower and Upper Jurassic forms (Toarcian and Kimmeridgian), with also significant populations of Westphalian and Lower Cretaceous forms, implying derivation from northeast England. Upper Cretaceous (Chalk) forms are consistently present in small quantities, while Palaeocene to Oligocene dinoflagellate cysts and Quaternary microplankton and miospores will derive from the North Sea (Riding, 2001).

The 'marly drift' tills, including the Weybourne Town Till Member (Tables 3, 4; Lee et al., 2004b) are pale grey or buff, massive, highly consolidated diamictons. They comprise almost entirely re-constituted chalk and black-hearted, fresh flints, with a minor Jurassic input. This is reflected in their allochthonous palynology, which is dominated by Upper Cretaceous forms, with Carboniferous and Jurassic forms rare (Riding, 1999, 2002b). Lee (2003) and Pawley et al. (2004) interpret these tills at Weybourne and Trimingham as subglacial. It is anticipated that ongoing work in north-east Norfolk will result in our raising more 'marly drift' members within the Sheringham Cliffs Formation.

Traditionally the 'marly drift' has been assigned to the Lowestoft Formation (Perrin et al., 1979; Ehlers et al., 1991; Lunkka, 1994; Bowen et al., 1999), in view of its high chalk content. However current BGS mapping shows that, throughout 
an outcrop extending from the north-east coast of Norfolk almost to Hunstanton, it is intimately associated with the brown sandy tills of the Sheringham Cliffs Formation. Together they form a major glacigenic complex which, at least in the east from the coast to Alby, rests upon the Lowestoft Formation. The detailed relationships of the two facies vary considerably and form the subject of further study. In the north east, for instance at Bacton Green, the brown sandy Bacton Green Till Member and the overlying 'marly drift' form separate mappable units (Lunkka, 1994), while inland around Hanworth, the 'marly drift' forms distinct masses within massive sandy till. Trial pits have so far failed to identify the nature of the junction here, but at Weybourne, the 'marly drift' has incorporated lensoid masses of the brown sandy Runton and Bacton Green tills as part of the subglacial deforming bed (Lee, 2003; Pawley et al., 2004; Lee et al.,2004b). Along the coast from West Runton to Weybourne, the two facies are interbedded in a complex of isoclinal folding to form the 'contorted drift' (Reid, 1882; Banham, 1975, 1988; Hart \& Boulton, 1991). These varying relationships must reflect differing conditions beneath the ice-sheet, with the 'contorted drift' here indicating soft sediment deformation under very high pore-water pressures, possibly occasioned by the icesheet impinging on a resistant ridge of Lowestoft Till below the present Cromer Ridge. The sandy tills around Hanworth and Alby shows no such deformation, since the ice-sheet would have been free-draining south of this ridge.

The Briton's Lane Formation largely comprises sands and gravels, including a major sandur, the Briton's Lane Sand and Gravel Member. This forms the core of the Cromer Ridge, a gravel ridge over $100 \mathrm{~m}$ high, with over $30 \mathrm{~m}$ of bedded sand and gravel exposed in the quarry at Briton's Lane (Moorlock et al., 2000b). Elsewhere, sands and gravels may be interpreted as till, since they are draped over an eroded topography of the Sheringham Cliffs Formation in a manner which can only be explained by direct deposition by melting ice, with ice-contact features being visible in the quarry at Stody (Hamblin, 2001). The mapping indicates that the formation includes the Blakeney Esker (Gale \& Hoare, 1986; Gray, 1997, Moorlock et al., 2002) and kames in the Glaven Valley (Moorlock et al., 2002). Analysis of the gravels at Briton's Lane showed predominantly flint with significant amounts of quartzite, resistant Cretaceous rocks, Triassic red sandstone and igneous and metamorphic rocks, but low values of Jurassic rocks and vein quartz (Table 3 ). The igneous rocks include dolerite, rhomb porphyry, feldspar porphyry, granite, granodiorite, diorite and gabbro, with the rhomb porphyry originating from the 0slofjord area of Norway. The metamorphic rocks were mostly schists, with only a few samples of gneiss. High values of amphibole and garnet in the heavy mineral analyses, and low values of apatite, imply North Sea derivation.

\section{Chronology of the Pre-Devensian tills}

The easiest formation to date is the Lowestoft Formation, traditionally ascribed to the Anglian glaciation, MIS 12, since this was the most extensive British glaciation and is correlated with the most prominent of the isotopic peaks representing magnitude of ice volume (Shackleton \& Turner, 1967; Bowen et al., 1999; Helmke et al., 2003). This has been confirmed by relating the glaciation to the terrace aggradations of the River Thames (Gibbard, 1977), demonstrating that the Thames was diverted to its present course by the Anglian ice sheet in MIS 12. More recently, organic deposits overlying the Lowestoft Till have been dated as MIS 11 at Hoxne, by U-series/ESR (Grün \& Schwarcz, 2000), and at Marks Tey, Essex, by U-series (Rowe et al., 1999).

The Happisburgh Formation underlies the Lowestoft Formation, but traditionally it has been considered to date from the same glaciation, because of a lack of intervening interglacial deposits and in view of the model of co-existing ice-sheets (Hart \& Boulton, 1991; Lunkka, 1994). However, this model has not been supported by our mapping and analytical work, and indeed the fact that the allochthonous palynology implies that the two formations have similar sources in north-east England and eastern Scotland make it unlikely, since this would require two very different deposits to derive from the same source area during the same glaciation. There are however a variety of indications that the formations represent separate glaciations. There is a strong unconformity between them, with the Lowestoft Formation resting on a deeply eroded topography cut in the Happisburgh Formation in southeast Norfolk. The Lowestoft/Walcott till is also much less weathered than the Happisburgh/Corton tills, which weather to form the 'Norwich Brickearth' (Rose et al., 1999). Also the Lowestoft Till incorporates clasts of calcrete derived from the Happisburgh Formation (Hopson \& Bridge, 1987; Candy, 2002), implying a sufficient time gap between the two formations to allow calcrete to form within the Happisburgh Formation.

Recently, more compelling evidence has been found in the terrace deposits of the Bytham River, a pre-Anglian river that flowed from the English Midlands to the sea near Lowestoft until it was overrun and destroyed by the Lowestoft Formation ice advance (Rose, 1989, 1994). Large, angular erratic clasts of far-travelled rocks including mica schist, granite, Carboniferous limestone, dolerite and porphyry, and also till balls apparently derived from the Happisburgh glacial advance, have been recorded in the Kirby Cane Sands and Gravels, which form the Timworth Terrace deposits of the Bytham River at Leet Hill (Rose et al., 2000; Lee et al., 2004a). Since this terrace is separated from the Lowestoft advance, which finally overran the Bytham river, by at least one temperate episode represented by organic deposits at High Lodge (Ashton et al., 1992) and Witham on the Hill (Gibbard \& Peglar, 1989), it follows that 
the Happisburgh and Lowestoft are separate glaciations. If the Lowestoft Glaciation dates from MIS 12, then an MIS 16 date is considered most likely for the Happisburgh Glaciation, since this is the next major cold peak in the oxygen isotope scale, assuming that the British Ice Sheet acted in phase with global and regional patterns of ice volume (Lee et al., 2004a). This proposed age does raise a major problem with regard to microtine rodent stratigraphy, since Arvicola terrestris cantiana occurs in the Cromer Forest-bed Formation beneath the Happisburgh Till, and this is considered to have first appeared within continental Europe in MIS 15 (Preece \& Parfitt, 2000; Banham et al., 2001). However, the correlation of rodent biostratigraphy over wide spatial areas is ambiguous due to inadequacies in the Cromerian record of the Netherlands (Vandenberghe, 2000) and to various evolutionary problems (Lee et al., 2004a).

Our mapping has now demonstrated that the Sheringham Cliffs Formation is present throughout almost the whole width of North Norfolk, from the east coast almost to Hunstanton, and it is thus believed that this is the till present at Tottenhill near Kings Lynn (Rowe et al., 1997), although unfortunately the Tottenhill pit has been restored and is not now available for sampling. At this site the till is recorded as passing upwards into laminated clays and sands and then peat, and U-series determinations on the peat indicate an MIS 9 age (Rowe et al., 1997). It is thus proposed that the till at Tottenhill, and the Sheringham Cliffs Formation, are of MIS 10 age. The high chalk content of the 'marly drift' invites a correlation with the Oadby Till of the English Midlands (Rice 1968, 1981): this has been correlated by Sumbler $(1995,2001)$ with terraces of the Thames catchment that are dated by amino acid ratios to MIS 10 (Bridgland, 1994; Sumbler, 1995). In the Midlands the terrace sequence only extends back to MIS 10 (Keen, 1999), implying that river development began as the MIS 10 ice wasted. However an alternative possibility is that the Bacton Green Member, which is the lowest member of the Sheringham Cliffs Formation and not directly connected to the 'marly drift', may date from the MIS 12 Lowestoft Glaciation, with the 'marly drift' and the remainder of the Sheringham Cliffs Formation dating from MIS 10 (Lee, 2003).

The Briton's Lane Formation rests upon a deeply eroded topography cut into the Sheringham Cliffs Formation, and differs from the pre-existing formations in that it retains constructional geomorphology in the form of the Cromer Ridge, the Blakeney Esker, and the kames in the Glaven Valley. This suggests that it is significantly younger than the Sheringham Cliffs and Lowestoft formations, since no such constructional geomorphology is found associated with British Anglian deposits in East Anglia or the Midlands. However it is not likely to be Devensian (MIS 2) since it is entirely unlike the Trias-rich Devensian glacigenic deposits which can be seen in Norfolk between Hunstanton and Morston. Thus it is proposed that it dates from MIS 6, which forms a major peak on the oxygen isotope scale (Funnell, 1995), and that it correlates with the Basement Till at Bridlington (Catt, 1991) and with the outwash gravels of the Tottenhill Member of the Nar Valley Formation in Norfolk (Gibbard et al., 1991, 1992, Lewis \& Rose, 1991). It is also correlated with the Dutch Saalian glaciation, which is age-constrained by MIS 7 and MIS 5e organic deposits (Vandenberghe et al., 1993). It is notable that the Dutch deposits are similarly of Scandinavian origin, and have similar landforms, including push-moraines on the scale of the Cromer Ridge (Ehlers et al., 1984).
Happisburgh Formation (OIS 16?)

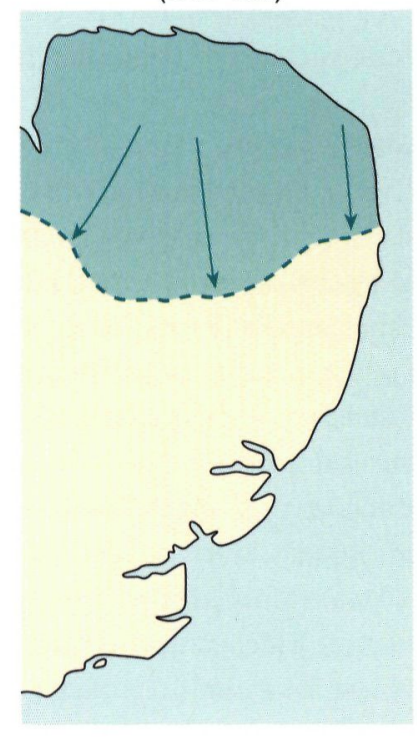

Lowestoft Formation (OIS 12)

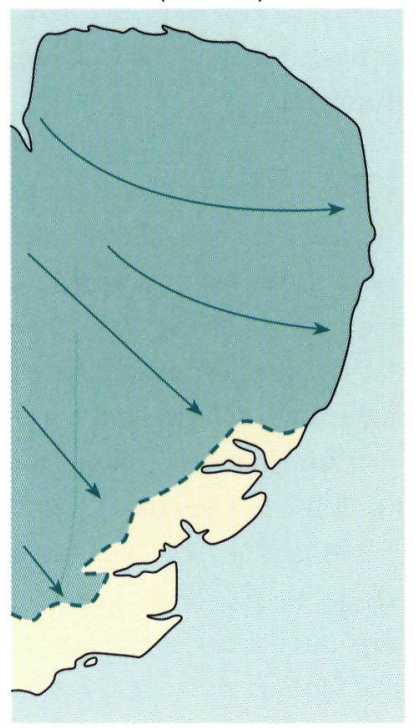

Sheringham Cliffs Formation (OIS 10?)

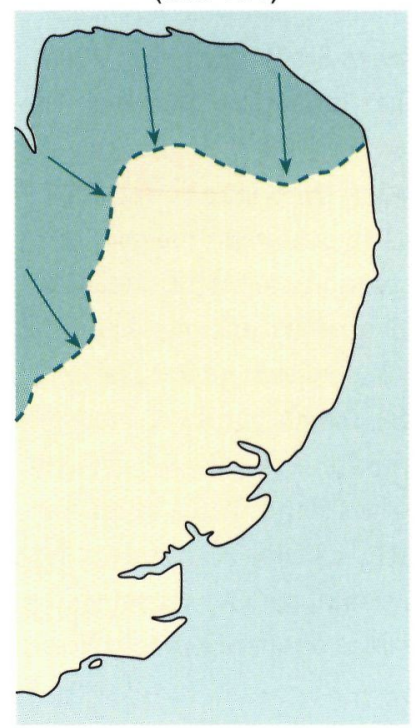

Briton's Lane Formation (OIS 6?)

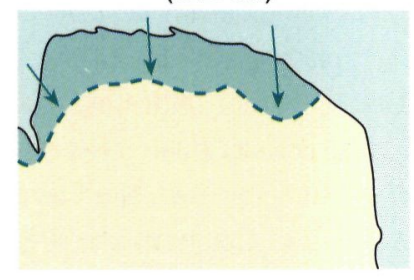

Holderness Formation (OIS 2)

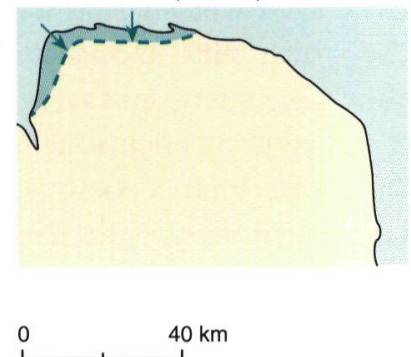

Figure 2. Inferred glacial limits (dashed lines) and ice flow paths (arrowed) for the five glaciations believed to have reached Norfolk. 


\section{Conclusions}

Detailed geological mapping, combined with analytical work, have led to the evolution of a robust lithostratigraphy that can now be applied with confidence. Four pre-Devensian formations are recognised, replacing the North Sea Drift and Lowestoft formations of the traditional model. Inferred glacial limits and ice-flow paths are shown in Fig. 2, although except in the case of the Lowestoft Formation these limits must remain provisional since our mapping so far has been largely in north and north-east Norfolk. The Happisburgh Formation is restricted to eastern Norfolk and northeast Suffolk, and is characterised by generally massive, sandy tills with derivation from northeast England, eastern Scotland and the North Sea. The overlying Lowestoft Formation is present at surface over most of East Anglia, but absent from much of north Norfolk where it was either not deposited or has been removed by the succeeding Sheringham Cliffs Glaciation. It is characterised by chalky till containing much Jurassic material, derived from north-east England and Scotland and entering the present area from the west. The Sheringham Cliffs Formation is present along the whole width of north Norfolk and is characterised by both brown sandy tills and very chalky 'marly drift'. These were derived from the north and NNW. It is widely overlain along the whole of its outcrop by the Briton's Lane Formation, dominantly flint gravels but divisable into both sandur and till deposits. This is the only deposit found to have a Scandinavian erratic component.

Although there is significant variation in the direction of derivation of the pre-Devensian glacigenic formations, no confirmation has been found for the traditional model of co-existing Scandinavian and Eastern British ice sheets, and the available evidence suggests that the formations represent several glaciations. Dating of the deposits is difficult as few organic units are available for correlation, and the level of confidence varies greatly for different formations. The baseline for our proposed dating scheme is the Lowestoft Formation, which is reliably dated as MIS 12 by both absolute determinations and river terrace correlations. Several lines of evidence suggest that the Happisburgh Formation dates from an earlier glaciation, particularly the presence of erratics and till balls derived from that glaciation found in the Timworth Terrace of the Bytham River. An age of MIS 16 is favoured here, but this could be amended as more is learned of pre-Anglian climatic stages. The Sheringham Cliffs Formation is believed to date from MIS 10 on the basis of absolute dating at Tottenhill and correlation with the Oadby Till in the Midlands, although an MIS 12 age cannot be ruled out for the lowest part of the formation, the Bacton Green Till. The Briton's Lane Formation is more confidently dated as MIS 6, on the basis of its constructional geomorphology and implied correlation with the Dutch Saalian; also its Scandinavian component clearly separates it from the preceding and the succeeding (Devensian) glaciations.

\section{Acknowledgements}

With respect to R.J.0.H., B.S.P.M., J.R.L., S.J.B. and J.B.R., this paper is published with the permission of the Executive Director, British Geological Survey (NERC).

\section{References}

Arthurton, R.S., Booth, S. J., Morigi, A.N., Abbott, M.A.W. \& Wood, C.J., 1994. Geology of the country around Great Yarmouth. Memoir of the British Geological Survey, Sheet 162 (England and Wales).

Ashton, N., Cook, J., Lewis, S.G. \& Rose, J. (eds). 1992. High Lodge: excavations by G. de G. Sieveking and J. Cook, 1988. British Museum (London): $192 \mathrm{pp}$.

Banham, P.H., 1968. A preliminary note on the Pleistocene stratigraphy of north-east Norfolk. Proceedings of the Geologists' Association 79: 281-285.

Banham, P.H., 1975. Glaciotectonic structures: a general discussion with particular reference to the contorted drift of Norfolk. In: Wright, A.A., \& Moseley, F. (eds): Ice Ages, Ancient and Modern. Geological Journal Special Issue No 6. Seel House Press (Liverpool): 69-94.

Banham, P.H., 1988. Polyphase glaciotectonic deformation in the Contorted Drift of Norfolk. In: Croot, D.G. (ed.): Glaciotectonics; Forms and Processes. Balkema (Rotterdam): 27-32.

Banham, P.H., Gibbard, P.L., Lunkka, J.P., Parfitt, S.A., Preece, R.C. \& Turner, C., 2001. A critical assessment of 'A new glacial stratigraphy for Eastern England'. Quaternary Newsletter 93: 5-14.

Boulton, G.S., Cox, F., Hart, J. \& Thornton, M., 1984. The glacial geology of Norfolk. Bulletin of the Geological Society of Norfolk 34: 103-122.

Bowen, D.Q., Lewis, S.G., Maddy, D., Gibbard, P.L., Preece, R.C., Campbell, S., Thomas, G.S.P., Sutherland, D.G., McCabe, A.M., Cameron, T.D.J. \& Holmes, R.A., 1999. A revised correlation of Quaternary deposits in the British Isles. Geological Society Special Report No. 23.

Bridgland, D.R., 1994. Quaternary of the Thames. Chapman and Hall (London): $441 \mathrm{pp}$.

Candy, I., 2002. Formation of a rhizogenic calcrete during a glacial stage (Oxygen Isotope Stage 12): its palaeoenvironmental stratigraphic significance. Proceedings of the Geologists' Association 113: 259-270.

Catt, J.A., 1991. Late Devensian glacial deposits and glaciations in eastern England and the adjoining offshore region. In: Ehlers, J., Gibbard, P.L. \& Rose, J. (eds): Glacial deposits in Britain and Ireland. Balkema (Rotterdam): 61-68.

Ehlers, J., \& Gibbard, P.L., 1991. Anglian glacial deposits in Britain and the adjoining offshore regions. In: Ehlers, J., Gibbard, P.L. \& Rose, J. (eds): Glacial deposits in Great Britain and Ireland. Balkema (Rotterdam): 17-21.

Ehlers, J., Meyer, K.-D. \& Stephan, H.-J., 1984. The pre-Weichselian glaciations of North-West Europe. Quaternary Science Reviews 3: 1-40.

Ehlers, J., Gibbard, P.L. \& Whiteman, C.A., 1991. The glacial deposits of northwestern Norfolk. In: Ehlers, J., Gibbard, P.L. \& Rose, J. (eds): Glacial deposits in Great Britain and Ireland. Balkema (Rotterdam): 223-232.

Funnell, B.M., 1995. Global sea-level and the (pen-)insularity of late Cenozoic Britain. In: Preece, R.C. (ed.): Island Britain: a Quaternary perspective. Geological Society Special Publication No 96: 3-13. 
Gale, S.J. \& Hoare, P.G., 1986. Blakeney Ridge sands and gravels. In: West, R. \& Whiteman, C.A. (ed.): The Nar Valley and north Norfolk: Field Guide. Quaternary Research Association (Cambridge): 94-95.

Gale, S.J. \& Hoare, P.G., 1991. Quaternary sediments: petrographic methods for the study of unlithified rocks. Wiley (Chichester).

Gibbard, P.L., 1977. Pleistocene history of the Vale of St Albans. Philosophical Transactions of the Royal Society B280: 445-483.

Gibbard, P.L. \& Peglar, S.M., 1989. Palynology of the fossiliferous deposits at Witham on the Hill, Lincolnshire. In: Keen, D.H. (ed.): The Pleistocene of the West Midlands: Field Guide. Quaternary Research Association (Cambridge): 131-133.

Gibbard, P.L., West, R.G., Andrew, R. \& Petitt, M., 1991. Tottenhill, Norfolk. In: Lewis, S.G., Whiteman, C.A. \& Bridgland, D.R. (eds): Central East Anglia and the Fen Basin: Field Guide. Quaternary Research Association (London): 131-143.

Gibbard, P.L., West, R.G., Andrew, R. \& Petitt, M., 1992. The margins of a Middle Pleistocene ice advance at Tottenhill, Norfolk, England. Geological Magazine 129: 59-76.

Gray, J.M., 1997. The origin of the Blakeney Esker, Norfolk. Proceedings of the Geologists' Association 108: 177-182.

Grün, R. \& Schwarcz, H.P., 2000. Revised open-system U-series/ESR age calculations for teeth from Stratum $C$ at the Hoxnian Interglacial type locality, England. Quaternary Science Reviews 19: 1151-1154.

Hamblin, R.J.O., 2000. A new glacial stratigraphy for East Anglia. Mercian Geologist 15: 59-62.

Hamblin, R.J.O., 2001. Geological notes and local details for 1 : 10000 sheet TG 03 SE (Briston). British Geological Survey Technical Report WA/00/34. (unpublished)

Hamblin, R.J.O., Moorlock, B.S.P. \& Rose, J., 2000. A new glacial stratigraphy for Eastern England. Quaternary Newsletter 92: 35-43.

Hamblin, R.J.O., Moorlock, B.S.P., Rose, J., Lee, J.R., Riding, J.B., Booth, S.J. \& Pawley, S.M., 2003. Revised Glacial Stratigraphy in Norfolk. Conference abstract: Integrated Land-Sea Stratigraphy, Utrecht.

Hart, J.K. \& Boulton, G.S., 1991. The glacial drifts of northeastern Norfolk. In: Ehlers, J., Gibbard, P.L. \& Rose, J. (eds): Glacial deposits in Britain and Ireland. Balkema (Rotterdam): 233-243.

Helmke, J.P., Bauch, H.A. \& Erlenkauser, H., 2003. Development of glacial and interglacial conditions in the Nordic seas between 1.5 and $0.35 \mathrm{Ma}$. Quaternary Science Reviews 22: 1717-1728.

Hopson, P.M. \& Bridge, D. McC., 1987. Middle Pleistocene stratigraphy in the lower Waveney Valley, East Anglia. Proceedings of the Geologists' Association 98: 171-185.

Keen, D.H., 1999. The chronology of Middle Pleistocene ('Wolstonian') events in the English Midlands. In: Andrews, P. \& Banham, P. (eds): Late Cenozoic environments and hominid evolution: a tribute to Bill Bishop. Geological Society (London): 159-168.

Lee, J.R., 2001. Genesis and palaeogeographical significance of the Corton Diamicton (basal member of the North Sea Drift Formation), East Anglia, UK. Proceedings of the Geologists' Association 112: 29-43.

Lee, J.R., 2003. Early and Middle Pleistocene Lithostratigraphy and Palaeoenvironments in northern East Anglia. Unpublished $\mathrm{PhD}$ thesis, Royal Holloway, University of London.
Lee, J.R., Rose, J., Riding, J.B., Moorlock, B.S.P. \& Hamblin, R.J.O., 2002. Testing the case for a Middle Pleistocene Scandinavian glaciation in Eastern England: evidence for a Scottish ice source for the tills within the Corton Formation of East Anglia. Boreas 31: 345-355.

Lee, J.R., Rose, J., Hamblin, R.J.O. \& Moorlock, B.S.P., 2004a. Dating the earliest lowland glaciation of eastern England: a pre-MIS 12 early Middle Pleistocene Happisburgh Formation glaciation. Quaternary Science Reviews 23: 1551-1566.

Lee, J.R., Booth, S.J., Hamblin, R.J.O., Jarrow, A.M., Kessler, H., Moorlock, B.S.P., Morigi, A.N., Palmer, A., Pawley, S.J., Riding, J.B. \& Rose, J. 2004b. A new stratigraphy for the glacial deposits around Lowestoft, Great Yarmouth, North Walsham and Cromer, East Anglia, UK. Bulletin of the Geological Society of Norfolk 53: 3-60.

Lewis, S.G. \& Rose, J., 1991. Tottenhill, Norfolk. In: Lewis, S.G., Whiteman, C.A. \& Bridgland, D.R. (eds): Central East Anglia and the Fen Basin: Field Guide. Quaternary Research Association (London): 145-148.

Lunkka, J.P., 1994. Sedimentation and lithostratigraphy of the North Sea Drift and Lowestoft Till Formations in the coastal cliffs of northeast Norfolk, England. Journal of Quaternary Science 9: 209-234.

Moorlock, B.S.P., Booth, S., Fish, P., Hamblin, R.J.O., Kessler, H., Riding, J., Rose, J. \& Whiteman, C.A., 2000a. A revised glacial stratigraphy of Norfolk. In: Lewis, S.G., Whiteman, C.A. \& Preece, R.C. (eds): The Quaternary of Norfolk and Suffolk: Field Guide. Quaternary Research Association (London): 53-54.

Moorlock, B.S.P., Booth, S., Fish, P., Hamblin, R.J.O., Kessler, H., Riding, J., Rose, J. \& Whiteman, C.A., 2000b. Briton's Lane Gravel Pit, Beeston Regis (TG 168 415). In: Lewis, S.G., Whiteman, C.A. \& Preece, R.C. (eds): The Quaternary of Norfolk and Suffolk: Field Guide. Quaternary Research Association (London): 115-117.

Moorlock, B.S.P., Hamblin, R.J.O., Rose, J. \& Lee, J.R., 2001. The occurrence of rhomb-porphyry within diamictons in north-east Norfolk. Quaternary Newsletter 95: 49-50.

Moorlock, B.S.P., Hamblin, R.J.O., Booth, S.J., Kessler, H., Woods, M.A. \& Hobbs, P.R.N., 2002. Geology of the Cromer district - a brief explanation of the geological map. Sheet explanation of the British Geological Survey. $1: 50000$ Sheet 131 Cromer (England and Wales).

Pawley, S.M., Rose, J., Lee, J.R., Moorlock, B.S.P. \& Hamblin, R.J.O., 2004. Early and Middle Pleistocene sedimentology and lithostratigraphy of Weybourne, northeast Norfolk, England. Proceedings of the Geologists' Association 115: 25-42.

Perrin, R.M.S., Davies, H. \& Fysh, M.D., 1973. Lithology of the Chalky Boulder Clay. Nature 245: 101-104.

Perrin, R.M.S., Rose, J. \& Davies, H., 1979. The distribution, variation and origins of pre-Devensian tills in eastern England. Philosophical Transactions of the Royal Society of London B287: 535-570.

Preece, R. C. \& Parfitt, S. A., 2000. The Cromer Forest-bed Formation: new thoughts on an old problem. In: Lewis, S.G., Whiteman, C.A. \& Preece, R.C. (eds): The Quaternary of Norfolk and Suffolk: Field Guide. Quaternary Research Association (London): 1-27.

Reid, C., 1882. The geology of the country around Cromer (explanation of Sheet $68 E$ ). Memoirs of the Geological Survey, England and Wales. Her Majesty's Stationery 0ffice (London).

Rice, R.J., 1968. The Quaternary deposits of central Leicestershire. Philosophical Transactions of the Royal Society of London A262: 459-509. 
Rice, R.J., 1981. The Pleistocene deposits of the area around Croft in south Leicestershire. Philosophical Transactions of the Royal Society of London B293: 385-418.

Riding, J.B., 1999. The palynology of eight samples from the tills of the North Norfolk coast. British Geological Survey Technical Report, WH/99/98R. 15 pp. (unpublished).

Riding, J.B., 2001. The palynology of three till samples from North Norfolk. British Geological Survey Internal Report, IR/01/77. 13 pp. (unpublished).

Riding, J.B., 2002a. A palynological investigation of till samples from the Cromer-North Walsham area, North Norfolk. British Geological Survey Internal Report, IR/02/154. 17 pp. (unpublished).

Riding, J.B., 2002b. A palynological study of a chalk-rich diamicton from Abbey Farm, near Hanworth, North Norfolk. British Geological Survey Internal Report, IR/02/174. 4 pp. (unpublished).

Rose, J., 1989. Stadial type sections in the British Quaternary. In: Rose, J. \& Schlüchter, C. (eds): Quaternary Type Sections: Imagination or Reality? Balkema (Rotterdam): 45-67.

Rose, J., 1994. Major river systems of central and southern Britain during the Early and Middle Pleistocene. Terra Nova 6: 435-443.

Rose, J., Lee, J.R., Moorlock, B.S.P. \& Hamblin, R.J.O., 1999. The origin of the Norwich Brickearth: micromorphological evidence for pedological alteration of sandy Anglian till in northeast Norfolk. Proceedings of the Geologists' Association 110: 1-8.

Rose, J., Candy, I. \& Lee, J.R., 2000. Leet Hill (TM 384 926): pre-glacial and glaciofluvial river deposits - with possible evidence for a major glaciation prior to the deposition of the Lowestoft Till. In: Lewis, S.G., Whiteman, C.A. \& Preece, R.C. (eds): The Quaternary of Norfolk and Suffolk: Field Guide. Quaternary Research Association (London): 207-217.

Rowe, P.J., Richards, D.A., Atkinson, T.C., Bottrell, S.H. \& Cliff, R.A., 1997. Geochemistry and radiometric dating of a Middle Pleistocene peat. Geochimica et Cosmochimica Acta 61: 4201-4211.

Rowe, P.J., Atkinson, T.C. \& Turner, C., 1999. U-series dating of Hoxnian interglacial deposits at Marks Tey, Essex, England. Journal of Quaternary Science 14: 693-702.

Shackleton, N.J. \& Turner, C., 1967. Correlation between marine and terrestrial Pleistocene successions. Nature 216: 1079-1082.

Sumbler, M.G., 1995. The terraces of the rivers Thame and Thames and their bearing on the chronology of glaciation in central and eastern England. Proceedings of the Geologists' Association 106: 93-106.

Sumbler, M.G., 2001. The Moreton Drift: a further clue to glacial chronology in central England. Proceedings of the Geologists' Association 112: 13-27.

Vandenberghe, J., 2000. A global perspective of European chronostratigraphy for the past $650 \mathrm{ka}$. Quaternary Science Reviews 19: 1701-1707.

Vandenberghe, J., Roebroeks, W. \& Van Kolfschoten, T. (eds), 1993. Maastricht-Belvédère: stratigraphy, palaeoenvironment and archaeology of the Middle and Late Pleistocene deposits; Part ii. Mededelingen Rijks Geologische Dienst 47: 91 pp. 